\title{
Quality Parameters of Sunflower (Helianthus annuus L.) Seeds and Seedlings under Various Storage Duration and Seed Invigoration
}

\author{
Rupa Das $^{1}$, Saikat Biswas ${ }^{2}$ and A. K. Mandal $^{3}$ \\ ${ }^{1}$ Department of Seed Science and Technology, ${ }^{2}$ Department of Agronomy, \\ Bidhan Chandra Krishi Vishwavidyalaya, Mohanpur, Nadia, West Bengal, India \\ ${ }^{3}$ Department of Seed Science and Technology, Institute of Agricultural Science, University of \\ Calcutta, Ballygaunge Circular road, Kolkata, West Bengal, India \\ *Corresponding author
}

\section{Keywords \\ Invigoration, Seed quality, Sunflower, Seed storage \\ Article Info \\ Accepted: \\ 05 January 2020 \\ Available Online: \\ 10 February 2020}

\section{A B S T R A C T}

\section{Introduction}

Apart from food grains, oilseed crops also have high significance in human diet. Besides, in food processing and industrial sectors, oilseed crops hold good position over the years. With the drastic increase of human population, oilseed crops are now getting less focus as compared to food grain crops. Imbalance between demand and supply thus has made produce of oilseed crops costly. In order to make routine supply of oilseeds at 
low price to the consumers with no import from other countries, oilseed crop cultivation is now required to be paid adequate attention. Among the oilseeds, sunflower (Helianthus annuus L.) is an important crop which ranks $5^{\text {th }}$ after soybean, rape seed-mustard, groundnut and sesame. Sunflower cultivation in India in 2017-18 comprised $0.33 \mathrm{~m}$ ha with a production and productivity of 0.19 million tonnes and $590 \mathrm{~kg} \mathrm{ha}^{-1}$ respectively (NFSM, 2018).Major sunflower growing states in India are Karnataka, Maharashtra, Uttar Pradesh, Madhya Pradesh, Andhra Pradesh, Haryana, Punjab, Bihar, Orissa and West Bengal. Apart from providing good quality vegetable oil (46-52\%, high PUFA content), sunflower is known to supply cakes, bird food etc. Besides, it has some aesthetic value as flower in various decorations. Due to its short duration maturity, sunflower can be easily grown without sacrificing other major crops in cropping system. However, low productivity and gradual reduction in productivity of sunflower are now the matters of concern particularly in the present context of demand and supply gap of vegetable oil. Among various reasons for low and constant reduction in productivity of sunflower, sub optimum plant population in response of poor germination and seedling mortality is major one. Seed quality is the prime factor responsible for germination and stand establishment of a crop. In states of eastern India specially, in West Bengal, sunflower is grown mostly in winter season. Storage of sunflower seeds thus becomes a routine practice for sunflower growers. Poor atmospheric conditions specially, high temperature and relative humidity in eastern Indian states cause rapid deterioration of sunflower seed quality during storage. Further, harmful pathogenic infections reduce the quality of seeds (Saha and Mandal, 2016). Since use of optimum quality of seeds for sowing is one of the prime requisites for attaining high plant population, vigorous growth and high yield of a crop, maintenance of seed quality during storage urges for considerable attention. Among several methods for maintenance and enhance quality of seeds, seed invigoration is promising one. Various dry powder exposures have been reported to check seed quality deterioration in various crop seeds (Bhattacharya et al., 2015; Guha et al., 2012). Works by various researchers around the world have already proved the positive influence of seed invigoration with various materials (chemicals, crude plant materials, pharmaceutical powders etc.) on seed and seedling quality parameters of various crops (Basra et al., 2003). Another important factor responsible for seed quality is storage duration. Decision on maximum limit of seed storage duration without sacrificing the quality plays a crucial role to rearrange cropping pattern and to ensure good crop performance in the field. Keeping all these facts in mind, the present experiment was planned to observe seed and seedling quality parameters of sunflower under various storage period and seed invigoration.

\section{Materials and Methods}

The Experiment was carried out in the laboratory of Department of Seed Science and Technology, Institute of Agricultural Science, University of Calcutta, West Bengal, India in the year2015 to evaluate the seed and seedling quality of sunflower under varied storage duration and invigoration with powdered ingredients.

Experiment comprised two factors viz. storage duration and invigoration with powdered ingredients having 4 levels in each factor and thus involved 16 treatment combinations. New sunflower (Helianthus annuus L. cv. Morden) seeds just after harvesting were procured from the Agricultural Experimental Farm, University 
of Calcutta, Baruipur, West Bengal, India. Procured seeds were next cleaned and dried properly under sunlight for 2-3 days to reach a moisture content of $8 \%$.

Except $\mathrm{D}_{1}$ (No storage after harvest), the seeds were stored for 3 different durations $\left(\mathrm{D}_{2}\right.$ : Storage for 3 months after harvest, $\mathrm{D}_{3}$ : Storage for 6 months after harvest, $\mathrm{D}_{4}$ : Storage for 9 months after harvest) underexposures of 3 different powdered ingredients $\left(\mathrm{T}_{1}:\right.$ Red chilli powder (active ingredient, capsaicin) @ 1g/kg of seed, $\mathrm{T}_{2}$ : Bleaching powder (calcium hypochlorite) @ $2 \mathrm{~g} / \mathrm{kg}$ of seed and $\mathrm{T}_{3}$ : Finely powdered aspirin (active ingredient, orthoacetyl salicylic acid) @ $50 \mathrm{mg} / \mathrm{kg}$ of seed) along with $\mathrm{T}_{4}$ : Control (dry seeds) in the laboratory inside rubber stoppered glass bottles at room temperature $\left(28 \pm 1{ }^{\circ} \mathrm{C}\right)$ under ambient conditions, which were shaken once daily for a week for proper mixing with invigoration ingredients.

Thereafter, physiological and bio-chemical tests were done accordingly the methods as prescribed by International Seed Testing Association (ISTA, 2009). Observations on seed quality parameters included germination percentage, root length, shoot length, seedling fresh and dry weights, vigour index and electrical conductivity. Vigour index of sunflower seedlings was estimated based on the following formula:

Vigour Index $=$ Germination percentage $\times$ Seedling length

Data obtained on mentioned parameters were statistically analysed by following analysis of variance method as prescribed by Panse and Sukhatme (1985) through OP-Stat online portal and treatment means were compared through critical differences (CD) as suggested by Gomez and Gomez (1984) at 5\% level of significance.

\section{Results and Discussion}

\section{Effect of storage duration on seed quality parameters of sunflower}

Experimental results (Table 1) explored that various seed quality parameters of sunflower significantly varied according to different durations in storage. Maximum germination percentage $(89.72 \%)$ of sunflower seeds was noted when fresh seeds were not stored after harvesting $\left(\mathrm{D}_{1}\right)$ and it gradually decreased with the increment of storage duration. Imbalance of chromosomal activities and reduction of activities of antioxidant enzymes under increment of seed storage condition (Kapilan and Thiagarajah, 2015) might be some factors responsible behind such poor germination of stored sunflower seeds. The result was in conformity with the findings of Shelar and Shaikh (2002) and Isaac et al. (2016) in soybean seeds. Abebaw et al., (2016) in tef seeds also reported that germination of seeds declined with the elongation of storage period. Following the trend of germination, fresh seeds $\left(\mathrm{D}_{1}\right.$ i.e.no storage after harvesting) showed greater root length $(10.62 \mathrm{~cm})$, shoot length $(4.257 \mathrm{~cm})$, fresh weight $(1.518 \mathrm{~g})$ and dry weight $(0.168$ g) of seedlings as compared to the stored seeds. Poor seed germination and reductions of enzymatic and physiological activities resulting in dormancy might be some reasons for poor performance of sunflower seedling growth under storage conditions. Sultana et al. (2016) also obtained poor seedling growth in case of rice under storage condition. However, among different storage durations, sunflower seeds stored for 3 months $\left(D_{2}\right)$ comparatively performed better (root length: $9.12 \mathrm{~cm}$, shoot length: $3.651 \mathrm{~cm}$, seedling fresh weight: $1.259 \mathrm{~g}$ and seedling dry weight: $0.162 \mathrm{~g}$ ) (Table 1). Since vigour index is dependent on seed germination and seedling length, maximum vigour index (1341.80) was also achieved from freshly 
harvested seeds prior to storage $\left(D_{1}\right)$ which was next followed by seeds stored for 3 months $\left(\mathrm{D}_{2}\right)$ (855.95). Poorest vigour index (208.62) from seeds stored for 9 months $\left(D_{4}\right)$ suggested that increase of storage duration resulted in loss of seed quality. Decline of vigour index of sunflower seedlings with increase of storage duration was also found by Sajjanet al. (2013). However, on a contrary, electrical conductivity of sunflower seeds got increased with the increment of storage duration. Seeds stored for 9 months $\left(D_{4}\right)$ exhibited highest electrical conductivity value $\left(1.268 \mathrm{ds} \mathrm{m}^{-1}\right)$ which was closely followed by seeds with 6 months storage $\left(\mathrm{D}_{3}\right)(1.017 \mathrm{ds}$ $\left.\mathrm{m}^{-1}\right)$. Fresh seeds $\left(\mathrm{D}_{1}\right.$ i.e. no storage after harvesting) recorded lowest value of electrical conductivity $\left(0.048 \mathrm{ds} \mathrm{m}^{-1}\right)$ indicating the better quality of newly harvested seeds over stored ones. The result was in line with the findings of Naguib et al. (2011) and Abebaw et al. (2016) who stated that extension of storage period increased electrical conductivity of wheat and tef seeds respectively. Disintegration of seed membrane, which is followed by electrolyte leakage (release of sugar, amino acids, enzymes, proteins, ions etc.) might be the reason of increase of electrical conductivity of stored seeds over fresh seeds (Noviana et al., 2007; Beedi et al., 2018). Grisi and Santos (2007) observed sunflower seed quality deterioration with increase in length of storage period.

\section{Effect of invigoration powdered ingredients on seed quality parameters of sunflower}

Beside different seed storage durations, invigoration of sunflower seeds with various powdered ingredients also exerted statistically significant influence on all the mentioned seed quality parameters (Table 1). Among the powdered ingredients, red chilli powder $\left(\mathrm{T}_{1}\right)$ exhibited greatest germination percentage
$(61.75 \%)$ of sunflower seeds, which was next followed by bleaching powder $\left(\mathrm{T}_{2}\right)(60.26 \%)$ and both remained statistically indifferent to each other. Lowest germination percentage $(51.35 \%)$ from dry seeds $\left(\mathrm{T}_{4}\right)$ clearly depicted the positive influence of seed invigoration with various powdered ingredients on sunflower seeds. In the similar fashion, root length $(9.01 \mathrm{~cm})$, shoot length $(3.609 \mathrm{~cm})$, fresh weight $(1.270 \mathrm{~g})$ and dry weight $(0.158$ g) of sunflower seedlings were highly improved over control $\left(\mathrm{T}_{4}\right)$ when red chilli powder $\left(T_{1}\right)$ was used for seed invigoration which was closely followed by seed invigoration through bleaching powder $\left(\mathrm{T}_{2}\right)$ (root length: $8.64 \mathrm{~cm}$, shoot length: $3.464 \mathrm{~cm}$, seedling fresh weight: $1.149 \mathrm{~g}$ and seedling dry weight: $0.148 \mathrm{~g})$. Use of aspirin $\left(\mathrm{T}_{3}\right)$ did not influence those seed quality parameters so much. Saha and Mandal (2016) also observed positive influence of red chilli powder and bleaching powder on sunflower seed germination and seedling growth over aspirin treatment and control. In response to positive influence on germination and seedling length, vigour index of sunflower seedlings was observed maximum (855.36) when red chilli powder was used for seed invigoration which was closely followed by seed invigoration through bleaching powder $\left(\mathrm{T}_{2}\right)$ (797.54) (Table 1). Control or dry seeds $\left(\mathrm{T}_{4}\right)$ exposed lowest vigour index (579.26) due to devoid of positive effect of seed invigoration. Electrical conductivity (EC) was however highest $\left(0.684 \mathrm{ds} \mathrm{m}^{-1}\right)$ in aspirin treated sunflower seeds $\left(\mathrm{T}_{3}\right)$ which was statistically similar to control or dry seeds $\left(\mathrm{T}_{4}\right)\left(0.621 \mathrm{ds} \mathrm{m}^{-1}\right)$. Lowest EC $\left(0.547 \mathrm{ds} \mathrm{m}^{-1}\right)$ was recorded from sunflower seed invigoration through red chilli powder $\left(\mathrm{T}_{1}\right)$ which was however statistically at par with seed invigoration through bleaching powder $\left(\mathrm{T}_{2}\right)\left(0.580 \mathrm{ds} \mathrm{m}^{-1}\right)$. Red chilli powder has the active ingredient capsaicin which is a potential antioxidant against free radicals $\left(\mathrm{OH}^{\circ}\right.$ and peroxyl) (Nascimento et al., 2013) and undergoes 
scavenging of radicals by transferring hydrogen from phenolic hydroxyl group. Besides, red chilli powder on application to seeds, blocks lipid peroxidation and reduces electrolyte leakage by maintaining seed membrane integrity (Dey and Ghosh, 1993) and lowers down aldehyde production (Mandal et al., 2000). Besides, capsaicin in red chilli powder protects the seeds from pathogenic infection (Saha and Mandal, 2016). In the present experiment, that might be why, application of red chilli powder improved sunflower seed germination, seedling growth, vigour index and reduced electrical conductivity. Bleaching powder on the other hand contains halogen chlorine which stabilizes lipid double bond in seed membrane (Rudrapal and Basu, 1981) and scavenge free radicals (Pryor and Lasswell, 1975) when applied to seeds and thus results in high seed quality and seedling vigour (Farooq et al., 2008). The result from present experiment regarding the benefits of seed invigoration by bleaching powder has been earlier confirmed by Vidyadhar and Singh (2000) in maize and mustard seeds.

Interaction effect of storage duration and invigoration powdered ingredients on seed quality parameters of sunflower

Experimental results (Table 2 and Fig 1-7) clearly expressed that interaction of storage duration and invigoration powdered ingredients exerted statistically significant effects on various seed quality parameters of sunflower except germination percentage, seedling dry weight and electrical conductivity. However, maximum germination percentage $(94.40 \%)$ of sunflower seeds were observed when fresh seeds prior to storage was treated with red chilli powder $\left(\mathrm{D}_{1} \mathrm{~T}_{1}\right)$ which was next followed by fresh seeds (i.e. no storage) treated with bleaching powder $\left(\mathrm{D}_{1} \mathrm{~T}_{2}\right)$ (93.19\%). Germination percentage gradually decreased with increment of seed storage duration under treatment of powdered ingredients specially, with aspirin (Table 2 and Fig 1). Under no invigoration treatment (control) irrespective of storage duration sunflower seeds and seedlings showed low quality parameters. Lowest germination (19.63\%) of sunflower seeds was noticed when seeds were stored for 9 months without any invigoration powdered ingredients (control or dry seeds) $\left(\mathrm{D}_{4} \mathrm{~T}_{4}\right)$. Root length and shoot length of sunflower seedlings showed maximum value $(12.38 \mathrm{~cm}$ and $4.954 \mathrm{~cm}$ respectively) when fresh seeds without any storage were treated with red chilli powder $\left(\mathrm{D}_{1} \mathrm{~T}_{1}\right)$, followed by fresh seeds treated with bleaching powder $\left(\mathrm{D}_{1} \mathrm{~T}_{2}\right)$ (root length: $11.40 \mathrm{~cm}$ and shoot length: $4.584 \mathrm{~cm}$ ). Among different storage durations, seeds stored for 3 months comparatively exhibited better root length $(9.83 \mathrm{~cm})$ and shoot length $(3.933 \mathrm{~cm})$ with the treatment of red chilli powder $\left(\mathrm{D}_{2} \mathrm{~T}_{1}\right)$, followed by the same with the treatment of bleaching powder $\left(\mathrm{D}_{2} \mathrm{~T}_{2}\right)$ (root length: $9.66 \mathrm{~cm}$ and shoot length: $3.867 \mathrm{~cm}$ ).

Seeds stored for 9 months without any invigoration treatments $\left(\mathrm{D}_{4} \mathrm{~T}_{4}\right)$ produced lowest root and shoot lengths $(4.93 \mathrm{~cm}$ and $1.976 \mathrm{~cm}$ respectively) of sunflower seedlings (Table 2 and Fig 2and 3). Fresh and dry weights showed the similar trend of germination and seedling lengths with maximum (1.802 $\mathrm{g}$ and $0.177 \mathrm{~g}$ respectively) and minimum $(0.532 \mathrm{~g}$ and $0.091 \mathrm{~g}$ respectively) values were observed from fresh seeds with the treatment of red chilli powder $\left(\mathrm{D}_{1} \mathrm{~T}_{1}\right)$ and seeds stored for 9 months without any invigoration treatments $\left(\mathrm{D}_{4} \mathrm{~T}_{4}\right)$ respectively (Table 2 and Fig 4 and 5). Vigour index of sunflower seedlings in response to seed germination and seedling lengths attained maximum value (1636.05) when fresh seeds were treated with red chilli powder $\left(D_{1} T_{1}\right)$ followed by the fresh seeds treated with bleaching powder $\left(\mathrm{D}_{1} \mathrm{~T}_{2}\right)$ (1489.37) (Table 2 and Fig 6). 
Table.1 Effects of storage duration and powdered ingredients on seed quality parameters of sunflower

\begin{tabular}{|c|c|c|c|c|c|c|c|}
\hline Treatments & $\begin{array}{l}\text { Germination } \\
(\%)\end{array}$ & $\begin{array}{l}\text { Root length } \\
(\mathrm{cm})\end{array}$ & $\begin{array}{l}\text { Shoot length } \\
(\mathrm{cm})\end{array}$ & $\begin{array}{l}\text { Seedling fresh } \\
\text { weight } \\
\text { (g) }\end{array}$ & $\begin{array}{c}\text { Seedling dry } \\
\text { weight } \\
\text { (g) }\end{array}$ & $\begin{array}{l}\text { Vigour } \\
\text { index }\end{array}$ & $\begin{array}{c}\text { Electrical } \\
\text { conductivity } \\
\left(\mathbf{d s} \mathbf{~ m}^{-1}\right)\end{array}$ \\
\hline \multicolumn{8}{|c|}{ Duration in storage } \\
\hline $\mathbf{D}_{1}$ & 89.72 & 10.62 & 4.257 & 1.518 & 0.168 & 1341.80 & 0.048 \\
\hline $\mathbf{D}_{2}$ & 66.90 & 9.12 & 3.651 & 1.259 & 0.162 & 855.95 & 0.099 \\
\hline $\mathbf{D}_{3}$ & 46.96 & 7.42 & 2.971 & 1.013 & 0.150 & 490.34 & 1.017 \\
\hline $\mathbf{D}_{4}$ & 26.20 & 5.62 & 2.253 & 0.698 & 0.102 & 208.62 & 1.268 \\
\hline $\operatorname{S.Em}( \pm)$ & 1.28 & 0.01 & 0.001 & 0.002 & 0.003 & 14.58 & 0.022 \\
\hline C.D. $(p=0.05)$ & 3.70 & 0.02 & 0.002 & 0.004 & 0.008 & 42.18 & 0.064 \\
\hline \multicolumn{8}{|c|}{ Powdered ingredients } \\
\hline $\mathbf{T}_{1}$ & 61.75 & 9.01 & 3.609 & 1.270 & 0.158 & 855.36 & 0.547 \\
\hline $\mathbf{T}_{2}$ & 60.26 & 8.64 & 3.464 & 1.149 & 0.148 & 797.54 & 0.580 \\
\hline $\mathbf{T}_{\mathbf{3}}$ & 56.42 & 7.82 & 3.132 & 1.105 & 0.144 & 664.56 & 0.684 \\
\hline $\mathbf{T}_{4}$ & 51.35 & 7.31 & 2.927 & 0.963 & 0.131 & 579.26 & 0.621 \\
\hline $\operatorname{S.Em}( \pm)$ & 1.28 & 0.01 & 0.001 & 0.002 & 0.003 & 14.58 & 0.022 \\
\hline C.D. $(p=0.05)$ & 3.70 & 0.02 & 0.002 & 0.004 & 0.008 & 42.18 & 0.064 \\
\hline
\end{tabular}

$\mathbf{T}_{1}$ : Red chilli powder (active ingredient, capsaicin) @ 1g/kg of seed, $\mathbf{T}_{2}$ : Bleaching powder (calcium hypochlorite) @ $2 \mathrm{~g} / \mathrm{kg}$ of seed, $\mathbf{T}_{3}$ : Finely powdered aspirin (active ingredient, ortho-acetyl salicylic acid) @ $50 \mathrm{mg} / \mathrm{kg}$ of seed, $\mathbf{T}_{\mathbf{4}}$ : Control (dry seeds) and $\mathbf{D}_{\mathbf{1}}$ :No storage after harvest, $\mathbf{D}_{\mathbf{2}}$ : Storage for 3 months after harvest, $\mathbf{D}_{3}$ : Storage for 6 months after harvest, $\mathbf{D}_{\mathbf{4}}$ : Storage for 9 months after harvest 
Table.2 Interaction effect of storage duration and powdered ingredients on seed quality parameters of sunflower

\begin{tabular}{|c|c|c|c|c|c|c|c|}
\hline $\begin{aligned} & \text { Duration in storage } \\
\times & \text { Powdered ingredients }\end{aligned}$ & $\begin{array}{c}\text { Germination } \\
(\%)\end{array}$ & $\begin{array}{l}\text { Root length } \\
(\mathrm{cm})\end{array}$ & $\begin{array}{l}\text { Shoot length } \\
(\mathrm{cm})\end{array}$ & $\begin{array}{c}\text { Seedling } \\
\text { fresh weight } \\
\text { (g) }\end{array}$ & $\begin{array}{l}\text { Seedling dry } \\
\text { weight } \\
\text { (g) }\end{array}$ & $\begin{array}{l}\text { Vigour } \\
\text { index }\end{array}$ & $\begin{array}{l}\text { Electrical } \\
\text { conductivity } \\
\left(\mathbf{d s ~ ~ m ^ { - 1 } )}\right.\end{array}$ \\
\hline$D_{1} T_{1}$ & 94.40 & 12.38 & 4.954 & 1.802 & 0.177 & 1636.05 & 0.029 \\
\hline $\mathbf{D}_{1} \mathbf{T}_{2}$ & 93.19 & 11.40 & 4.584 & 1.502 & 0.170 & 1489.37 & 0.040 \\
\hline$D_{1} T_{3}$ & 86.60 & 9.36 & 3.752 & 1.418 & 0.170 & 1135.48 & 0.069 \\
\hline $\mathrm{D}_{1} \mathbf{T}_{4}$ & 84.71 & 9.33 & 3.736 & 1.352 & 0.153 & 1106.32 & 0.054 \\
\hline $\mathbf{D}_{2} \mathbf{T}_{1}$ & 68.82 & 9.83 & 3.933 & 1.314 & 0.177 & 947.05 & 0.034 \\
\hline $\mathbf{D}_{2} \mathbf{T}_{2}$ & 67.47 & 9.66 & 3.867 & 1.312 & 0.170 & 912.80 & 0.052 \\
\hline $\mathbf{D}_{2} \mathbf{T}_{3}$ & 66.50 & 9.12 & 3.651 & 1.266 & 0.163 & 849.55 & 0.237 \\
\hline $\mathbf{D}_{2} \mathbf{T}_{4}$ & 64.83 & 7.87 & 3.153 & 1.142 & 0.137 & 714.40 & 0.073 \\
\hline$D_{3} T_{1}$ & 54.60 & 7.67 & 3.075 & 1.092 & 0.157 & 586.69 & 1.009 \\
\hline $\mathbf{D}_{3} \mathbf{T}_{2}$ & 51.73 & 7.62 & 3.052 & 1.081 & 0.150 & 552.23 & 1.012 \\
\hline $\mathbf{D}_{3} \mathbf{T}_{3}$ & 45.27 & 7.29 & 2.916 & 1.052 & 0.150 & 461.79 & 1.025 \\
\hline $\mathrm{D}_{3} \mathrm{~T}_{4}$ & 36.23 & 7.11 & 2.843 & 0.825 & 0.143 & 360.66 & 1.021 \\
\hline $\mathrm{D}_{4} \mathrm{~T}_{1}$ & 29.17 & 6.16 & 2.473 & 0.873 & 0.122 & 251.66 & 1.114 \\
\hline $\mathbf{D}_{4} \mathbf{T}_{2}$ & 28.67 & 5.87 & 2.353 & 0.702 & 0.102 & 235.74 & 1.217 \\
\hline $\mathrm{D}_{4} \mathbf{T}_{3}$ & 27.33 & 5.52 & 2.209 & 0.683 & 0.093 & 211.40 & 1.406 \\
\hline $\mathbf{D}_{4} \mathbf{T}_{4}$ & 19.63 & 4.93 & 1.976 & 0.532 & 0.091 & 135.67 & 1.335 \\
\hline $\operatorname{S.Em}( \pm)$ & 2.55 & 0.01 & 0.001 & 0.003 & 0.006 & 29.15 & 0.044 \\
\hline C.D. $(p=0.05)$ & NS & 0.04 & 0.004 & 0.009 & NS & 84.37 & NS \\
\hline
\end{tabular}




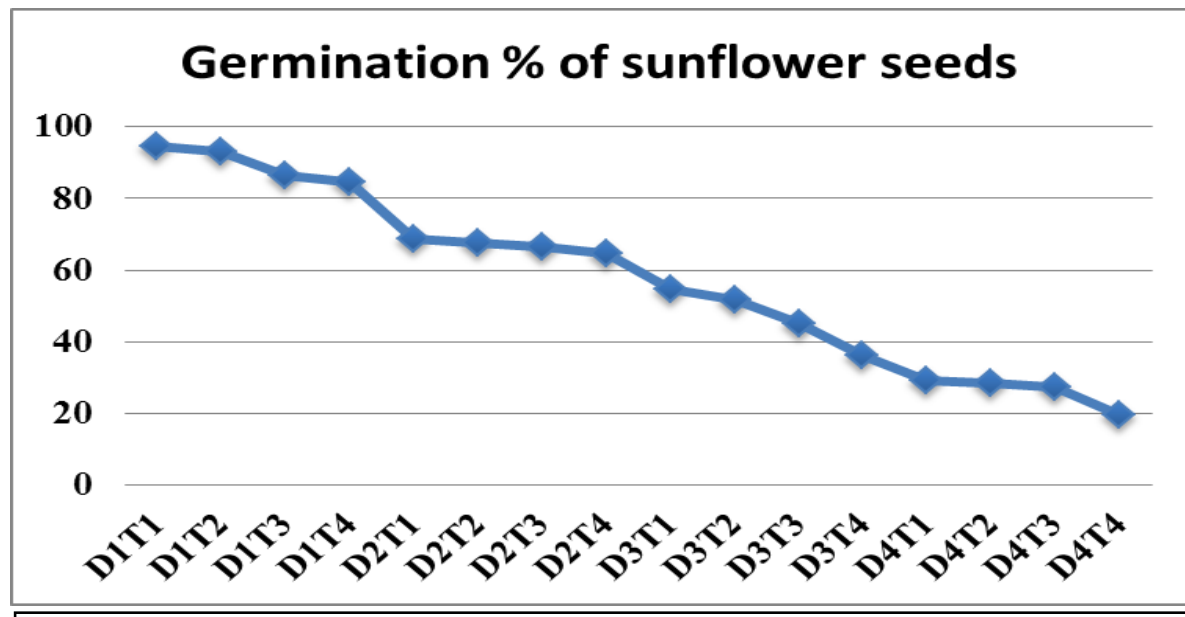

Fig 1: Interaction effect of storage duration and powdered ingredients on germination $\%$ of sunflower seeds

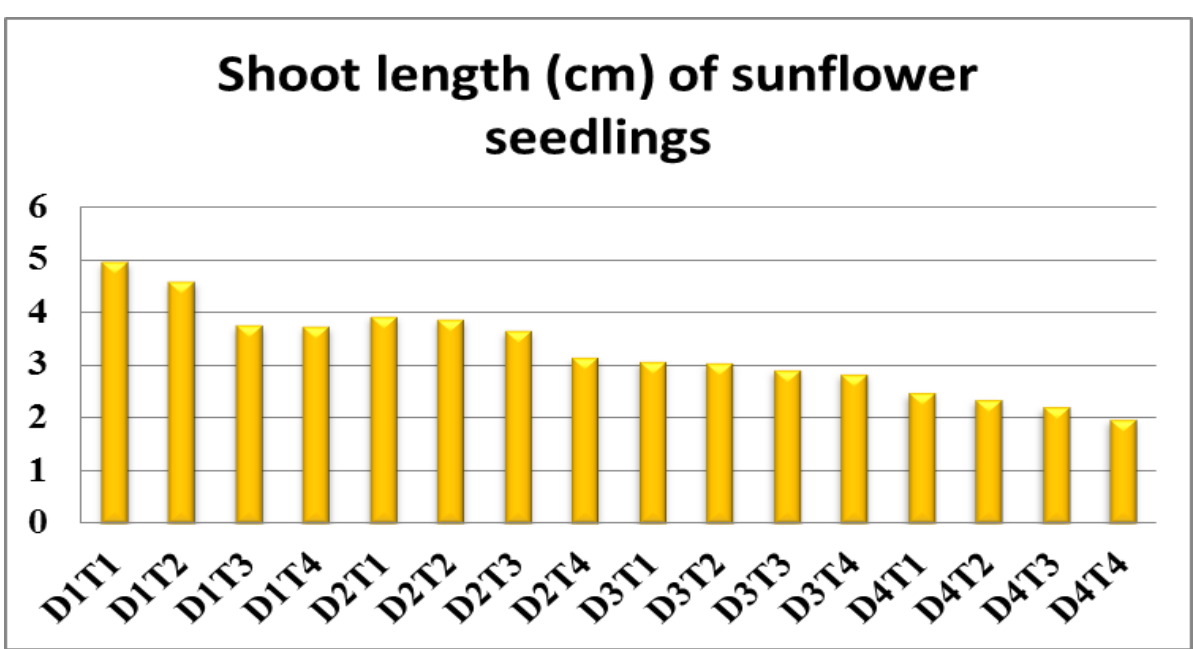

Fig 3: Interaction effect of storage duration and powdered ingredients on shoot length of sunflower seedlings

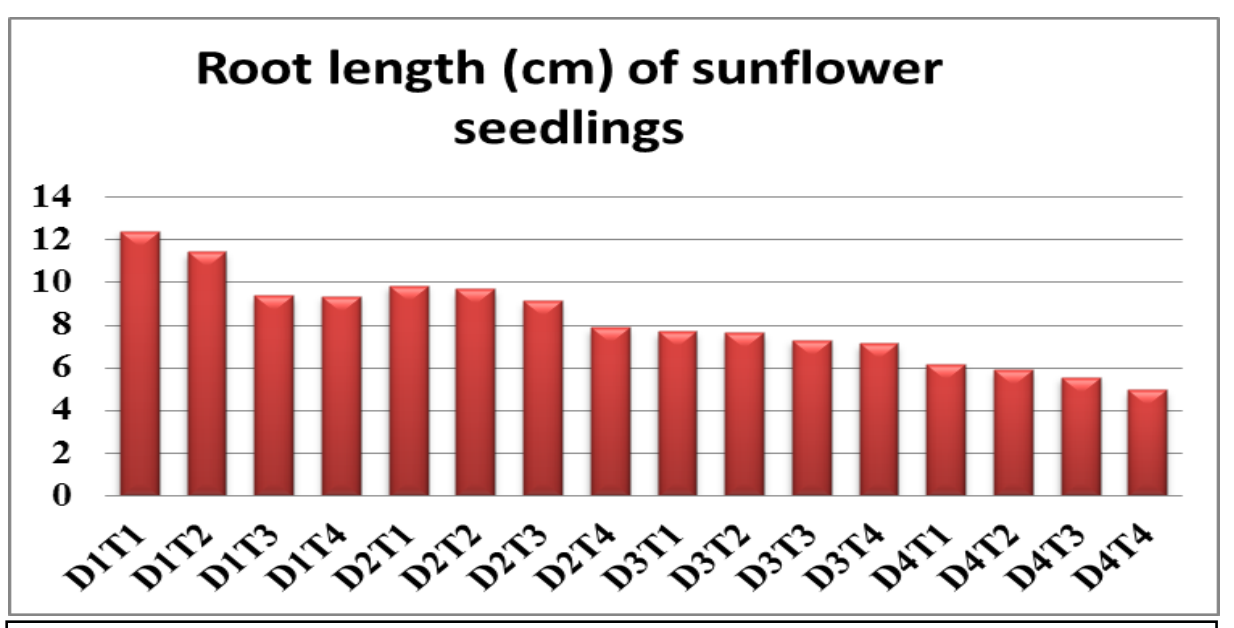

Fig 2: Interaction effect of storage duration and powdered ingredients on root length of sunflower seedlings

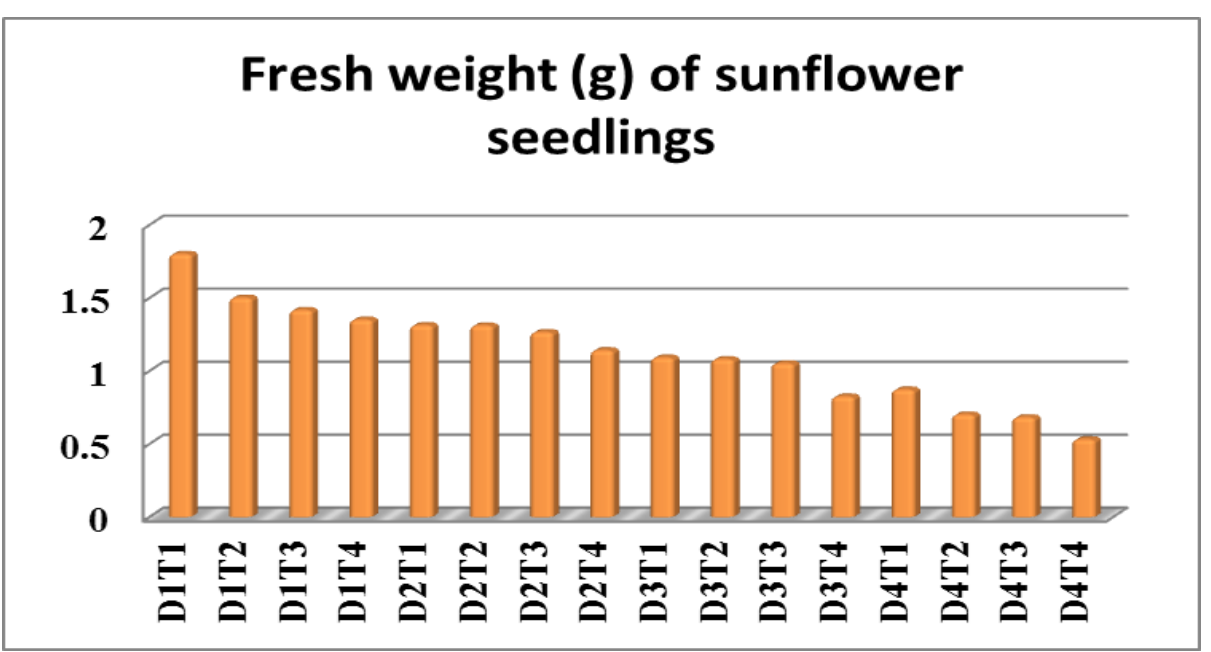

Fig 4: Interaction effect of storage duration and powdered ingredients on fresh weight of sunflower seedlings 


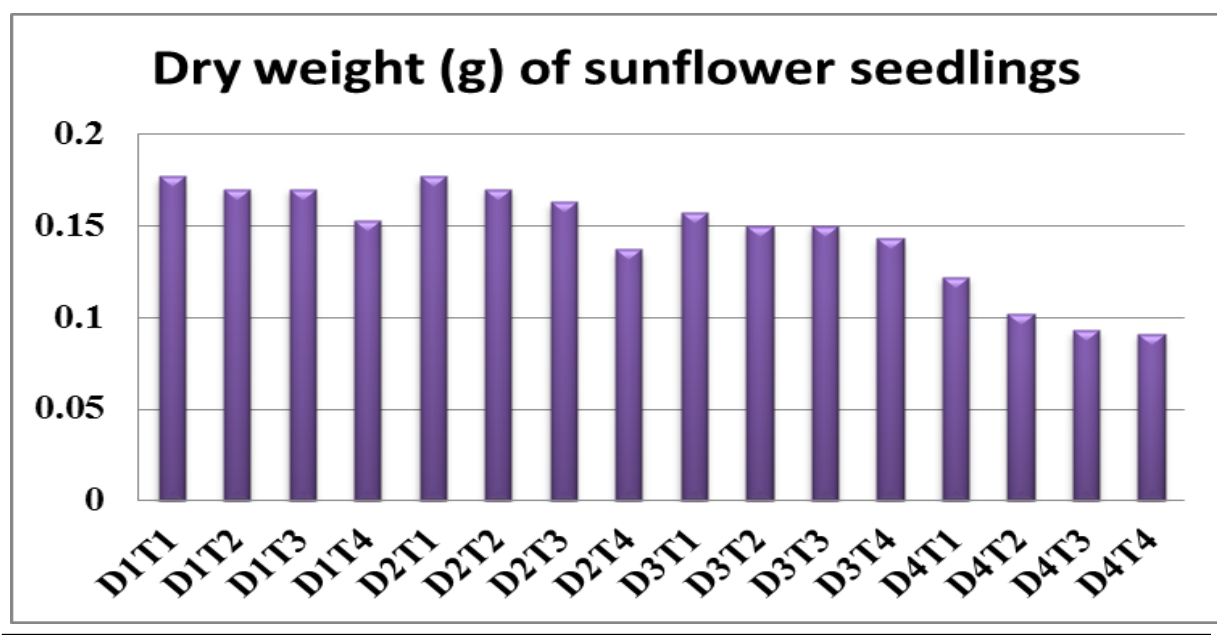

Fig 5: Interaction effect of storage duration and powdered ingredients on dry weight of sunflower seedlings

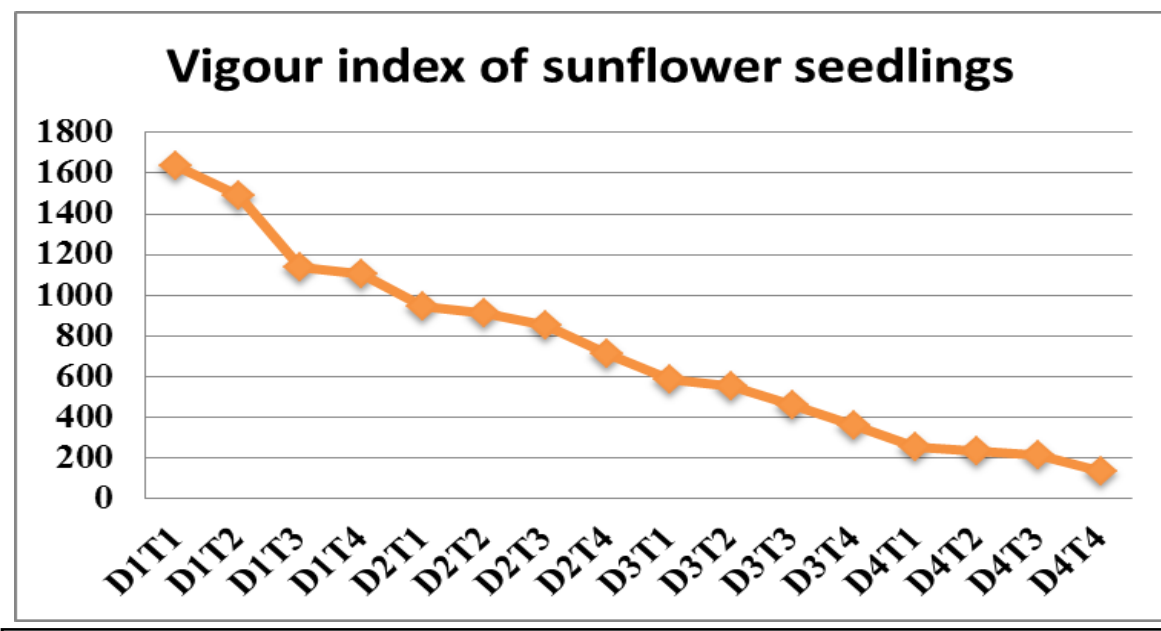

Fig 6: Interaction effect of storage duration and powdered ingredients on vigour index of sunflower seedlings

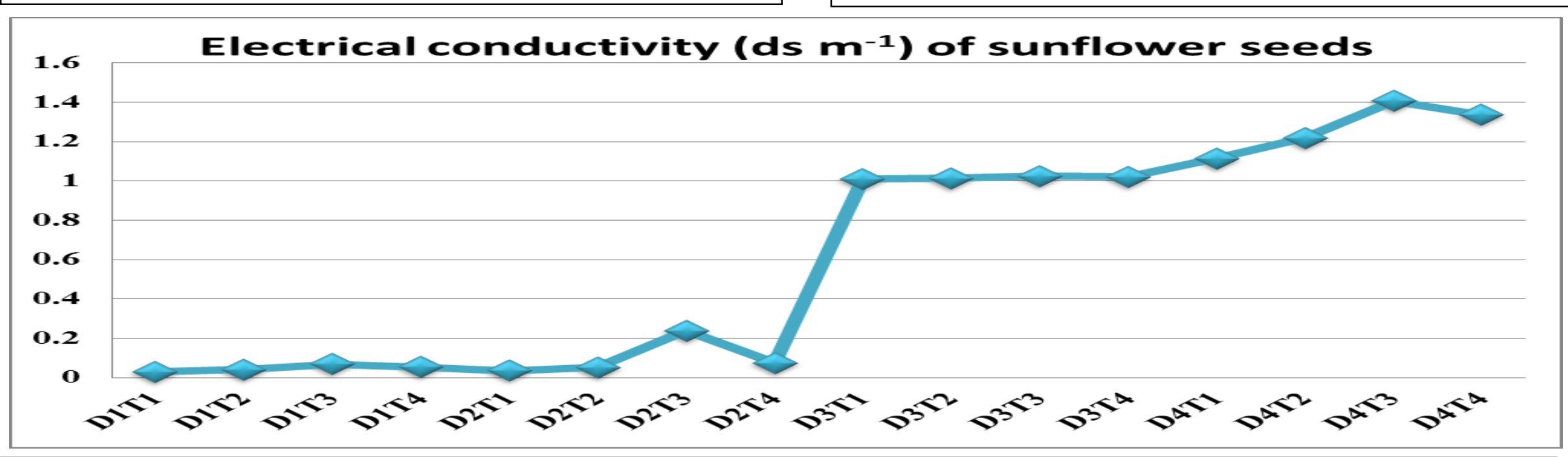

Fig 7: Interaction effect of storage duration and powdered ingredients on electrical conductivity of sunflower seeds 
With increment of storage durations irrespective of invigoration powdered ingredients, vigour index of sunflower seedlings showed gradual decrease. Lowest vigour index (135.67) was observed when sunflower seeds were stored for 9 months without any invigoration treatment $\left(\mathrm{D}_{4} \mathrm{~T}_{4}\right)$. However, electrical conductivity value (Table 2 and Fig 7) increased with the increment of seed storage duration. Highest electrical conductivity (1.406 ds m $\left.\mathrm{m}^{-1}\right)$ was observed from the sunflower seeds stored for 9 months with aspirin as powdered ingredient $\left(\mathrm{D}_{4} \mathrm{~T}_{3}\right)$, followed by the seeds stored for 9 months without any invigoration treatment $\left(\mathrm{D}_{4} \mathrm{~T}_{4}\right)$ $\left(1.335 \mathrm{ds} \mathrm{m}^{-1}\right)$. Lowest electrical conductivity $\left(0.029 \mathrm{ds} \mathrm{m}^{-1}\right)$ was exhibited by freshly harvested sunflower seeds treated with red chilli powder $\left(\mathrm{D}_{1} \mathrm{~T}_{1}\right)$ followed by freshly harvested seeds treated with bleaching powder $\left(\mathrm{D}_{1} \mathrm{~T}_{2}\right) \quad\left(0.040 \mathrm{ds} \mathrm{m}^{-1}\right)$. As days progresses for stored seeds, oxidative stress (production of reactive oxygen species), lipid peroxidation are increased, which damage seed membranes and cause electrolyte leakage (Bhattacharya et al., 2015; McDonald, 1999).

Use of red chilli or bleaching powders effectively reduce lipid peroxidation by scavenging free radicals and thereby maintain antioxidant enzymatic activities of seeds. The best seed and seedling quality parameters of sunflower thus were observed from fresh seeds treated with red chilli or bleaching powders $\left(\mathrm{D}_{1} \mathrm{~T}_{1}\right.$ and $\left.\mathrm{D}_{1} \mathrm{~T}_{2}\right)$.However, seeds stored up to 3 months by treating with red chilli or bleaching powders $\left(\mathrm{D}_{2} \mathrm{~T}_{1}\right.$ and $\left.\mathrm{D}_{2} \mathrm{~T}_{2}\right)$ performed better than further increment in storage period due to occurrence of lipid peroxidation within tolerable limit and additional beneficial role of those powders in removing free radicals and improving seed membrane integrity. Dry seeds stored for 9 months $\left(\mathrm{D}_{4} \mathrm{~T}_{4}\right)$ performed poorest due to high lipid peroxidation, membrane damage, release of electrolytes, high electrical conductivity, absence of antioxidant properties etc. and no invigoration treatment was there to repair the damage.

In conclusion, results from the present investigation stated the certain impacts of storage period and seed invigoration on sunflower seed and seedling quality parameters. In order to attain superiority in seed germination, seedling growth and vigour index of sunflower, it is recommended to the farmers to use fresh sunflower seeds without any storage by treating with red chilli powder @ $1 \mathrm{~g} / \mathrm{kg}$ of seed or bleaching powder @ 2 $\mathrm{g} / \mathrm{kg}$ of seed for sowing in the field. However, in the situation of waiting for suitable season or condition for sowing, sunflower seeds can be stored up to 3 months by treating with red chilli powder @ $1 \mathrm{~g} / \mathrm{kg}$ of seed or bleaching powder @ $2 \mathrm{~g} / \mathrm{kg}$ of seed, considering deterioration of seed quality under tolerable limit.

\section{References}

Abebaw, T., Mohamod, W. and Asefa, K. (2016).Effect of seed storage and varieties on seed quality of tef (Eragrostistef (Zucc.) Trotter). Agricultural Research \& Technology, 2(4): 00102-00109.

Basra, S.M.A., Zia, M.N., Mehmood, T., Afzal, I. and Khaliq, A. (2003) Comparison of different invigoration techniques in wheat Triticum aestivum L. seeds. Pak. J. Arid Agr., 5: 11-17.

Beedi, S., Macha, S.I., Gowda, B.B., Savitha, A.S. and Kurnallikar, V. (2018). Effect of seed priming on germination percentage, shoot length, root length, seedling vigour index, moisture content and electrical conductivity in storage of kabuli chickpea c.v., MNK-1 (Cicer arietinum L.). Journal of Pharmacognosy and Phytochemistry, 7(10): 2005-2010. 
Bhattacharya, S., Chowdhury, R. and Mandal, A. K. (2015).Seed invigoration treatments for improved germinability and field performance of soybean (Glycine max (L.) Merill). Indian Journal of Agricultural Research, 49: $32-38$.

Dey, A.K. and Ghosh, J.J. (1993). Ultraviolet radiation-induced lipid peroxidation in liposomal membrane: modification by capsaicin. Phytother. Res., 7: 87-89.

Farooq, M., Basra, S.M.A., Rehman, H. and Saleem, B.A. (2008). Seed priming enhances the performance of late sown wheat (Ttriticum aestivum L.) by improving chilling tolerance. J. Agron. Crop Sci., 194: 55-60.

Gomez, K.A. and Gomez, A.A. (1984).Statistical procedures for agricultural research. John Wiley \& Sons, New York.

Grisi, P.U. and Santos, C.M. (2007). Influência do armazenamento, nagerminação das sementes de girasol. Horizonte Cientifico, 1(7): 14-17.

Guha, P., Biswas, J., De, B.K. and Mandal, A.K. (2012).Post-harvest dry and wet physiological seed treatments for improved storability and field performance of okra (Abelmoschus esculentus L.). Indian Journal of Agricultural Research, 46: 16-22.

Isaac, O.T., Sewah, E.A., Apuri, S., Banful, B.K. and Amoah, S. (2016). Effect of storage periods on seed quality characteristics of three soybean (Glycine $\max (\mathrm{L})$ Merrill) varieties. International Journal of Scientific Research in Science, Engineering and Technology, 2(4): 823-830.

ISTA (2009). International rules for seed testing. Annex to chapter 7: Seed health testing. Seed health testing methods. International Seed Testing Association, Bassersdorf, Switzerland.

Kapilan, R. and Thiagarajah, M. (2015).Effect of aging on the germination characteristics and enzyme activity of sunflower seeds. International Journal of Research and Innovations in Earth Science, 2(6): 147-150.

Mandal, A.K., De, B.K., Basu, R.N. and Saha, R. (2000).Seed invigoration treatments for improved storability, field emergence and productivity of soybean (Glycine max L.). Seed Sci. and Technol., 28: 201-207.

McDonald, M.B. (1999). Seed deterioration: physiology, repair and assessment. Seed Sci. and Technol., 27: 177-237.

Naguib, Adly, N, Mohamed, E.A.I. and ElAidy, N.A. (2016).Effect of storage period and packaging material on wheat (Triticum aestivum L.) seed viability and quality. Egypt. J. Agric. Res., 89(4): 1481-1497.

Nascimento, P.L.A., Nascimento, T.C.E.S., Ramos, N.S.M., Silva, G.R., Camara, C.A., Silva, T.M.S., Moreira, K.A. and Porto, A.L.F. (2013). Antimicrobial and antioxidant activities of pimenamalaguenta (Capsicum frutscens). African J. Microbiol. Res., 7: 3526-3533.

NFSM (National Food Security Mission) (2018). Status paper. Retrieved from https:// www.nfsm.gov.in

Noviana, I., Diratmaja, A., Qadir, A. and Dan Faiza, C.S. (2007)0. Estimation of deterioration of soybean (Glycine max L. Merr) seeds during storage. Agros Agriculture Journal, 19(1): 1-12.

Panse, V.G. and Sukhatme, P.V. (1985). Statistical methods for Agricultural workers. Indian Council of Agricultural research publication. New Delhi: 8789.

Pryor, W.A. and Lasswell, L.D. (1975). Dielsalder and 1,4-diradical intermediates in the spontaneous polymerization of venyl monomers. In: Adv. Free Radical Chem. (Ed. Williams, G.H.), 5: 27. 
Rudrapal, A.B. and Basu, R.N. (1981).Use of chlorine and bromine in controlling mustard seed deterioration. Seed Res., 9: 188-191.

Saha, D. and Mandal, A.K. (2016). Seed invigoration treatments in different seed sizes of sunflower (Helianthus annuus L.) for maintenance of vigour, viability and yield potential. Indian Journal of Agricultural Research, 50 (1) 2016: 2226

Sajjan, A.S., Jolli, R.B. and Balikai, R.A. (2013).Studies on containers and seed treatments on seed quality in sunflower during storage. Agric. Sci. Digest, 33(2): 150-153.
Shelar, V.R. and Shaikh, N. (2002).Soybean seed quality during storage. Seed Technology Research. Agricultural Review, 29(2): 125-131.

Sultana, N., Ali, M.Y., Jahan, M.S. and Yasmin, S. (2016). Effect of storage duration and storage devices on seed quality of boro rice variety BRRI dhan 47. Journal of Plant Pathology \& Microbiology, 8(1): 1-6.

Vidyadhar, B. and Singh, B.G. (2000). Effect of seed treatment with halogens on yield and yield attributes in maize hybrid $\mathrm{BH}-$ 1001. Indian J. Plant Physiol., 5: 385386.

\section{How to cite this article:}

Rupa Das, Saikat Biswas and Mandal, A. K. 2020. Quality Parameters of Sunflower (Helianthus aпnиus L.) Seeds and Seedlings under Various Storage Duration and Seed Invigoration. Int.J.Curr.Microbiol.App.Sci. 9(02): 76-87.

doi: https://doi.org/10.20546/ijcmas.2020.902.010 